This is the accepted version of a forthcoming article that will be published by Springer in Feminist Review: https://link.springer.com/journal/volumesAndlssues/41305

Accepted version downloaded from SOAS Research Online: http://eprints.soas.ac.uk/24349/

\title{
Dystopia as Liberation: Disturbing Femininities in Contemporary Thailand
}

Rachel Harrison, Professor of Thai Cultural Studies, Department of South East Asia, SOAS University of London, 10 Thornhaugh Street, London WC1H 0XG

E:rh6@soas.ac.uk

Abstract:

Despite the stereotypical, outsider view of Thailand as a thriving hub of international sex tourism, traditional and local constructions of Thainess instead privilege the position of the "good" Thai woman - a model of sexual propriety, demure physicality and aesthetic perfection. This is the image of femininity that is heralded by Thailand's Tourist Authority and by government agencies alike as a marketable symbol of cultural refinement and national pride. But this disturbing, "utopian" construction of femininity might for some be considered a dystopia shaped by forms of power centred on elite urban rule.

In mainstream definitions of Thainess the monstrous and grotesque inverses of "good" womanhood are located in the "dystopian" visions of rural-based folk traditions that abound with malevolent female spirits and demons, and in the contemporary Thai horror films that draw on these tropes. Adopted by Thai feminists and by street protestors in Bangkok at times of recent political unrest, portrayals of a "monstrous-feminine" have been adopted as central to a carnivalesque strategy of response and resistance to elite discourses of control. 
This is the accepted version of a forthcoming article that will be published by Springer in Feminist Review: https://link.springer.com/journal/volumesAndlssues/41305

Accepted version downloaded from SOAS Research Online: http://eprints.soas.ac.uk/24349/

Such forces serve to symbolically disturb and destabilise middle class constructions of a utopian vision of Thainess with Bangkok as its cultural core.

This paper examines instances of how and why the counter-strategy of primitivism and monstrosity has developed, and the extent to which it translates "dystopian" expressions of female sexuality in new imaginaries of "dystopia" as a space of liberation from stultifying cultural and political norms.

Key words: Thai cinema; Thai culture; Thai politics; horror films; monstrousfeminine; Yingluck Shinawatra; Kham Phaka

\section{Acknowledgements:}

A preliminary version of this paper was presented in the "Queering Sexuality(ies) in Asia Seminar Series 2014/15" at the Centre for Postcolonial Studies, Goldsmiths, University of London. I would like to thank Sanjay Seth, Rajyashree Pandey and Chris Berry for their comments, together with the anonymous reviewers and the editors of Feminist Review. 
This is the accepted version of a forthcoming article that will be published by Springer in Feminist Review: https://link.springer.com/journal/volumesAndlssues/41305

Accepted version downloaded from SOAS Research Online: http://eprints.soas.ac.uk/24349/

Dystopia as Liberation: Disturbing Femininities in Contemporary Thailand

To be a woman means, first and foremost, to be courteous, polite and gentle, and to be aware of that for which one should rightly be proud, that about which one should be humble, that behaviour which is appropriate, and that which is not.

Thai female novelist Kor Surangkhanang, Chua chiwit [For a Lifetime], first published in 1946

Utopias and dystopias can exist side by side, even in the same moment. Which one you're in depends entirely on your point of view. [...] the relationship between our world and utopias or dystopias of all stripes is a complicated one. [...]Every utopia contains a dystopia. Every dystopia contains a utopia.

Naomi Alderman, "Dystopian dreams: how feminist science fiction predicted the future". The Guardian, 25 March 2017.

This is a dystopian sci-fi, a country beyond Brave New World.

Kong Rithdee, Life Editor, Bangkok Post. 22 April 2017 
This is the accepted version of a forthcoming article that will be published by Springer in Feminist Review: https://link.springer.com/journal/volumesAndlssues/41305

Accepted version downloaded from SOAS Research Online: http://eprints.soas.ac.uk/24349/

Introduction

On 22 May 2014 General Prayut Chan-ocha assumed power in a military coup that toppled the majority-elected government of Yingluck Shinawatra, the first woman to have ever held the post of Thai Prime Minister. Three years on, Prayut remains firmly at the helm. This paper does not seek to present Yingluck's premiership as either utopian or feminist: she was largely ushered into power on a ticket from her billionaire, elder brother, the exiled populist politician Thaksin Shinawatra, who had himself been removed as PM by a military coup in September 2006; and, furthermore, Yingluck's government was marred, like that of so many others before her, by accusations of extensive corruption. ${ }^{1}$ Rather, the analysis that follows focuses on the gendered dimensions of power in contemporary Thailand, their relationship to representations of female sexuality,

${ }^{1}$ In January 2015 Yingluck was impeached for corruption in a rice-subsidy scheme overseen under her premiership. See 'Thailand impeaches Yingluck Shinawatra over rice scheme', $B B C$ News, 23 January 2015. Available at: http://www.bbc.co.uk/news/world-asia-30928835 [last accessed 27 January 2017]. Thaksin was sentenced in absentia in 2008 to two years imprisonment for corruption. See 'Former Thai PM Thaksin found guilty of corruption', The Guardian, 21 October 2008. Available at: https://www.theguardian.com/world/2008/oct/21/thaksin-thailandcorruption [last accessed 27 January 2017]. However, neither was alone in facing such charges and accusations. As the New York Times obituary for former PM Chatichai Choonhavan (1988-1991), for example, opined, "he also led what came to be known as the "buffet cabinet," a ministerial line-up whose excesses and corruption led to his Government's replacement by a military leadership. He was known for his blithe repetition of the phrase "No problem" when criticized for his Government's excesses." (See Seth Mydans, 'Chatichai Choonhavan, 76, ExPrime Minister of Thailand', The New York Times, 7 May 1998. Available at: http://www.nytimes.com/1998/05/07/world/chatichai-choonhavan-76-exprime-minister-of-thailand.html, [last accessed 27 January 2017]. For further discussions of corruption in Thai politics and business in the 1990s see, for example, Pasuk and Baker 1998, pp. 256-268; and Pasuk and Baker 2000, pp. 127-131. 
This is the accepted version of a forthcoming article that will be published by Springer in Feminist Review: https://link.springer.com/journal/volumesAndlssues/41305

Accepted version downloaded from SOAS Research Online: http://eprints.soas.ac.uk/24349/

and the opportunities taken to create alternative representations of feminine potency. In the current socio-political milieu this entails a deliberately carnivalesque construction of "dystopia" as an expression of release from the stultifying association between state-endorsed utopia and its idiosyncratic and fundamentally undemocratic definitions of "goodness" and morality. An example is to be found in the wording of the catchy, post-coup d'état theme song, penned by General Prayut himself and played at regular intervals to date. Entitled "Return Happiness to Thailand," and set to music performed by the Royal Thai Army band, the song cheerfully reminds its listeners that:

We offer to guard and protect you with our hearts

This is our promise

Today the nation is facing menacing danger

The flames are rising

Let us be the ones who step in, before it is too late

To bring back love, how long will it take?

Please, will you wait? We will move beyond disputes

We will do what we promised. We are asking for a little more time.

And the beautiful land will return

We will do with sincerity

All we ask of you is to trust and have faith in us

The land will be good soon. ${ }^{2}$

2 The translation is courtesy of Khaosod English online newspaper. 
This is the accepted version of a forthcoming article that will be published by Springer in Feminist Review: https://link.springer.com/journal/volumesAndlssues/41305

Accepted version downloaded from SOAS Research Online: http://eprints.soas.ac.uk/24349/

A full rendition of the song, together with English subtitles and accompanying images suggestive of the utopian vision to be achieved by military intervention $\begin{array}{lllll}\text { can } & \text { be } & \text { found } & \text { Youtube }\end{array}$ https://www.youtube.com/watch?v=hpFYaHTvFFo $\quad$ and https://www.youtube.com/watch?v=5g7D-HCg7JM). ${ }^{3}$

As masculinised authority draws its strength from an alignment with a conservative and urban, "refined" and aestheticised traditional culture to manufacture an enforced utopia of regulated Thainess, the feminine is prescribed the burden of symbolising "goodness", modelled on courtly tradition and on centralised notions of propriety. What options then for radical reimagining and resistance from the periphery and the unvoiced? How might deeply rooted, archaic, mythical and historical beliefs in the monstrous and abject nature of the maternal body be redeployed to powerful and playful effect? And what subaltern languages of self-expression might be explored in the necessary invention of a "dystopia" of liberation?

To identify answers to these questions, this paper focuses on contemporary Thai politics and protest through the optic of gender and sexual expression. It interrogates the cultural dimensions of attacks on former PM Yingluck through reference to her physical body as sexualised and maternal, desirable yet monstrous and abject. It probes the relationship of the "pure" female body to cultural constructions of moral "goodness" and national wellbeing. Analyses are based not only on current events and their media coverage but on examples

${ }^{3}$ Last accessed 4 September 2016. 
This is the accepted version of a forthcoming article that will be published by Springer in Feminist Review: https://link.springer.com/journal/volumesAndlssues/41305

Accepted version downloaded from SOAS Research Online: http://eprints.soas.ac.uk/24349/

drawn from contemporary Thai literature, cinema and popular culture as well folklore, mythology and cultural criticism. This array of material is selected within the disciplinary field of cultural studies, deploying a range of cultural texts to read the significance of the "good, the bad and the ugly" in the construction of gendered power in Thailand. I explore the potential for reading this material with reference to Barbara Creed's psychoanalytical feminist theory of the "monstrous-feminine" (1993 and 2004), though mindful of its cultural specificities, despite its own claim to degrees of universality. The limitations of this theoretical approach are felt in the complexities of the perception of the "self" that pertain in Siam/Thailand (the country changed its name from the former to the latter in 1939) and which contrast with those that underpin much Judeo-Christian philosophical thought.

\section{Orient(alis)ation Points}

Speaking outside the immediate field of Asian area studies on the question of women and Thailand usually attracts predictable audience responses relating to the established stereotypes of prostitution and sex tourism. This appears to be the common context in which Thai femininity is internationally envisioned and "comprehended". The Longman dictionary typified this when, in 1993, it included an unflattering description of Bangkok as a city "where there are a lot of prostitutes". ${ }^{4}$ As an undergraduate finishing up the first year of a Thai language

\footnotetext{
${ }^{4}$ It was, as a result, banned in Thailand. See 'Thais ban dictionary over 'city of prostitutes' slur'. The Independent, 5 July 1993. Available at:
} 
This is the accepted version of a forthcoming article that will be published by Springer in Feminist Review: https://link.springer.com/journal/volumesAndlssues/41305

Accepted version downloaded from SOAS Research Online: http://eprints.soas.ac.uk/24349/

degree in the early 1980s in London, the response from the travel agent to my attempt to book my virgin flight to Bangkok was, "Women don't go to Bangkok!" It was a "Boys Only" destination - a sort of low-rent, offshore Gentleman's Club with a rippling, raw underbelly. The only white women who had ever been to Bangkok, as far as the popular Western imaginary was concerned, was Victorian governess Anna Leonowens, epitomised by her seductive waltz with Yul Bryner as the Siamese King Mongkut in Rodgers and Hammerstein's catchy 1956 musical The King and I; and the French adventuress, Emmanuelle (played by Sylvie Kristel) in the eponymous soft-porn classic, first released in $1974 .{ }^{5}$ And there I was, trying to embark on a maiden voyage to Thailand less than a decade after the end of the war in Vietnam that had introduced the American GI to the erotic pleasures of R\&R, so firming up the foundations of a thriving, touristoriented sex industry catering to a wide array of tastes.

Fuelling the country's lascivious reputation as "The Brothel of Asia", international news and documentary coverage of Thailand from the 1980s onwards dealt almost entirely with the representation of Thai "girls" as petite Oriental whores-cum-victims, to be fucked and then rescued by gallant, whitemale interventions. Examples of this focus in English-language documentary filmmaking included the 1981 BBC documentary One Way Ticket to Hualampong, and Tim Cooper's 1988 piece for UK television's Channel 4, Foreign Bodies. Australian filmmaker Dennis 0’Rourke released his quasi-fictional documentary

http://www.independent.co.uk/news/world/thais-ban-dictionary-over-city-ofprostitutes-slur-1483226.html [last accessed 7 July 2016].

5 The film is based on an erotic novel by Emanuelle Arsan, the nom-de-plume of a Thai woman resident in France, Marayat Krasaesin. 
This is the accepted version of a forthcoming article that will be published by Springer in Feminist Review: https://link.springer.com/journal/volumesAndlssues/41305

Accepted version downloaded from SOAS Research Online: http://eprints.soas.ac.uk/24349/

The Good Woman of Bangkok in 1991, filmed in the aftermath of his divorce and telling the story of his own relationship with a sex worker called Aoi. O'Rourke's involvement in her life closes with his baleful conclusion that she is beyond his salvation from her inevitable downward trajectory (see: Berry, Hamilton and Jayamanne, 1997).

While the Western male tourist view and the international media gaze on Thailand pinpoints the plentiful availability of sexual favours for a cost, what they have largely overlooked, however, are the multifarious local forces that contextualise the picture of Thailand as they see and paint it. In the framework of these eminently Orientalist fantasies, their roots nurtured by a persisting colonial mind-set, the utopia/dystopia of Thailand's notorious sex tourism industry has become an overrepresented feature of the underlying complex interrelationship between local forms of power, local discourses of female sexuality, local manifestations of patriarchy and local norms of modernity, aesthetics and expression; albeit now intricately connected to the global.

It is the association between the three key terms of sexuality, aesthetics and power in relation to constructions of Thai femininity and hence its potential languages of disruption that I wish to further explore in this paper. My principle concern lies with how this series of seductive forces are combined, on the one hand, to construct a "utopian", state-approved image of feminine Thainess; and how, on the other hand, this construction can be subverted into an alternative and challenging, "dystopian" (body-) language of expression. I contextualise my discussion by pointing to particular forms of the feminine as they enact 
This is the accepted version of a forthcoming article that will be published by Springer in Feminist Review: https://link.springer.com/journal/volumesAndlssues/41305

Accepted version downloaded from SOAS Research Online: http://eprints.soas.ac.uk/24349/

prescribed social roles; and, by contrast, how they work both with and against high-brow and vernacular traditions to open up spaces of resistance and of liberation from pervasive forms of control.

\section{Thai Male Forces and the Female Body (-Politic)}

At the time of writing this paper, following the 7 August 2016 constitutional referendum by Thailand's interim, military-backed National Council for Peace and Order (NCPO) as a roadmap to "fully-functioning democracy" there is little sight of regime change on the horizon. ${ }^{6}$ Former army general Prayut Chan-ocha assumed power two years earlier in a coup that toppled the majority-elected government of Yingluck Shinawatra. The country's shift toward democracy, beginning with a move from absolute to constitutional monarchy in 1932, has always been characterised by a close involvement with the armed forces, as testified by the number of military coup d'états to have taken place. With nineteen attempted coups since 1932, twelve of which have been successful, Thailand stands among the most coup-prone nations of the world. In September 2006 the enforced departure by the military of Yingluck Shinawatra's elder brother Thaksin from the domestic political arena solidified an already growing divide between staunch monarchist, conservative, pro-Democrat Party "YellowShirts" on the one hand, and the sometimes-liberal-leaning, Thaksin-loving, pro-

\footnotetext{
${ }^{6}$ See, for example, Wassana Nanuam and Aekarach Sattaburut's report 'Prawit says election may be scrapped' in the Thai English-language daily, The Bangkok Post. Available at: http://www.bangkokpost.com/news/politics/977053/prawit-says-electionmay-be-scrapped [18 May 2016, last accessed 28 March 2017]
} 
This is the accepted version of a forthcoming article that will be published by Springer in Feminist Review: https://link.springer.com/journal/volumesAndlssues/41305

Accepted version downloaded from SOAS Research Online: http://eprints.soas.ac.uk/24349/

democracy "Red-Shirts" on the other. Despite her popularity among a majority electorate of Red-Shirt supporters however, Yingluck was deemed by her more vocal opponents to be unfit for office. Military intervention followed months of sustained protest by the Yellow-Shirt-aligned PDRC (People's Democratic Reform Committee) who drew cultural legitimacy from their allegiance to the Thai national flag. Sporting a range of accessories in red, white and blue, such as wristbands, and ribbons, braids and bows in their hair, they literally drowned out the majority democratic voice with a deafening chorus of whistles.

Rather than focus, however, on the politico-economic reasons that led to this division and unrest (for which see, for example, Pasuk and Baker 2002, 2004 and 2008; McCargo and Ukrist 2004; and Montesano, Pavin and Aekapol 2012) I want instead to draw specific attention to the discourses of sexualised power and "monstrous femininity" that were deployed in the protest against Yingluck's premiership by her opponents; and to examine the ways in which they are both symptomatic of and perpetuated by a deeply embedded cultural anxiety with regard to female potency in Thailand.

Unfavourable comments relating to Yingluck's gender, age, appearance, marital status and regional origins began to circulate soon after her rise to power in 2011: the fact that she was a woman hailing from the northern province of Chiangmai made her doubly peripheral to the power base centred in Bangkok. An online report by the Heinrich Böll Stiftung six months into the Yingluck premiership observed that, "Popular ways to debate her role have been through caricatures in the daily press [...] During the debate the public has focused on her 
This is the accepted version of a forthcoming article that will be published by Springer in Feminist Review: https://link.springer.com/journal/volumesAndlssues/41305

Accepted version downloaded from SOAS Research Online: http://eprints.soas.ac.uk/24349/

alleged personal weaknesses, which are directly and indirectly connected to her womanhood." 7 A clear example was provided in comments by the (subsequently assassinated) businessman Akeyuth Anchanbutr who alluded to Yingluck's Northern Thai background as incriminating evidence of her qualification to work in the commercial sex industry, alongside so many women from the same region: "I don't want to say this, because it might sound like I look down on women," wrote Akeyuth on his public Facebook page, "but the fact is, uneducated or lazy and stupid northern women will happily do work that normal women will not do, like prostitution. So a northern woman, who is incredibly unintelligent and stupid, but is simply brazen enough to take up the position [of PM], should know the profession she is actually best suited to."8

Slurs of similar inspiration were reiterated in print media and online cartoons, exemplified by a 2013 strip in the virulently anti-Thaksin national newspaper Phujatkan (The Manager), in which a massage parlour owner comments to a sole-remaining, Yingluck-look-alike, sex worker in the showroom: "You put all the customers off (sex) ... But if lots of red shirts come, you'll be pretty hot for them." 9 Penned by the elderly male political cartoonist "Bancha-Khamin"

\footnotetext{
7 See Huber, Elisabetha, 2012. "First female Prime Minister in Thailand: Stereotypes dominate debates". Available at: https://www.boell.de/en/navigation/asia-stereotypes-female-prime-ministerthailand-13836.html [last accessed 31 January 2017].

${ }^{8}$ Akeyuth's comments were widely reported in the Thai press. For further details see the online newspaper Prachathai. See "Akeyuth Anchanbutr curses northern women, slams Yingluck", 6 November 2011. Available at: http://www.prachatai.org/english/node/2876 [last accessed 31 January 2017]. ${ }^{9}$ See also the online blog by Thai feminist Kaewmala, and in particular her piece on the hate speech directed against Yingluck, "Thais are losing humanity and reason in consuming hate", 15 February 2014. Available at:
} 
This is the accepted version of a forthcoming article that will be published by Springer in Feminist Review: https://link.springer.com/journal/volumesAndlssues/41305

Accepted version downloaded from SOAS Research Online: http://eprints.soas.ac.uk/24349/

(pseud.), it was one of an extensive series of sketches ridiculing the former PM as a "Stupid Bitch" (E ngo), the title given to the book comprising select examples of the collection. ${ }^{10}$

Plumbing the same depths of obsession with Yingluck's sexual availability and her potential powers of seduction, the Thai (and British) press published a series of suggestive photographs of Yingluck's reception of Barrack Obama in November 2012. The images not only highlighted what was portrayed as her "inappropriate" flirtatiousness with the US President but in particular her potentially dark forces of bewitchment. (For reproductions, see, for example, Mail Online, 2012. ${ }^{11}$ ) She is captured looking up at him coquettishly while seductively holding his hand; throwing her head back in the rapturous laughter of suggested sexual abandon; or eyeing Obama voraciously, in the way a tigress might her prey. In its report of 22 November 2012 Manager Online ran the same photographs with the story that the relationship between the two was "excessively and abnormally sweet" (wan yoem koen pokati). ${ }^{12}$

https://thaiwomantalks.com/2014/02/15/thais-are-losing-humanity-andreason-in-consuming-hate/ [last accessed 31 January 2017]. 10 An online advertisement for "Bancha-Khamin"'s Stupid Bitch is available at https://www.se-ed.com/product/รวมการ์ตูนผ้จัดกวน-

อีโง่.aspx?no=9786165361170\#changlang

${ }^{11}$ See "The charmer-in-chief: Obama gets flirty as he schmoozes with Thai prime minister on first stop of historic Asia visit", Mail Online, 18 November 2012. Available at: http://www.dailymail.co.uk/news/article-2234978/PresidentBarack-Obama-schmoozes-Thai-PM-Yingluck-Shinawatra-stop-historic-Asiavisit.html [last accessed 31 January 2017].

12 See

http://www.manager.co.th/Around/ViewNews.aspx?NewsID=9550000142661 [last accessed 31 January 2017]. 
This is the accepted version of a forthcoming article that will be published by Springer in Feminist Review: https://link.springer.com/journal/volumesAndlssues/41305

Accepted version downloaded from SOAS Research Online: http://eprints.soas.ac.uk/24349/

By far the most disturbing indication of the fascination with Yingluck's sexualised body, however, came at an anti-Government protest in Bangkok in January 2014 from a well-known doctor and award-winning lecturer - Assistant Professor Prasert Wasinanukorn of Songkhlanakharin University's Faculty of Medicine. Demonstrative of the misogynistic collusion between disgust, control and desire, Dr Prasert entertained the gathered crowd of PDRC supporters by offering, among other things, to perform vaginal repair surgery should Yingluck fall pregnant; and to buy and change her sanitary towels for her should she agree to step down from office. In the event that she did step down, his recommendation to her was to assume an alternative career as a naked calendar girl, given that she had not yet reached the menopause.

Prasert's revelations concerning his wish to undertake this variety of intrusions into Yingluck's ordinarily private physical spaces exemplify a near-obsession with controlling and defiling the sexualized female body that is deemed to have betrayed the national, communal or familial good. Prasert's rabble-rousing speech derives not only from a real position of power, as a doctor over a patient/object; but also from a position of imagined "moral" authority, as the restoration of "good" (conservative/nationalist) forces over "bad".

Although seemingly aberrant, the tenor of Dr Prasert's remarks on the female body and on menstruation are by no means restricted to a handful of perverted individuals. The gathered crowd of whistle-blowing, flag-waving protestors responded to his performance with celebratory laughter and increasingly ecstatic clapping. The right-wing compere, Anchalee Paireerak was heard 
This is the accepted version of a forthcoming article that will be published by Springer in Feminist Review: https://link.springer.com/journal/volumesAndlssues/41305

Accepted version downloaded from SOAS Research Online: http://eprints.soas.ac.uk/24349/

screaming and whooping as she urged the doctor to raise the stakes in his challenge to Yingluck. ${ }^{13}$ Although some members of the medical establishment subsequently stepped in to advise against such crude forms of public oratory, ${ }^{14}$ Dr Prasert's remarks in fact reflect a deeply rooted attitude to women that has its origins in history, myth, and folklore, as I go on to examine below.

\section{Know your Knickers: The Thai Monstrous-Feminine}

Stories relating to the threat of female sexuality and the impurities of the female body are of course by no means unique to Siam/Thailand, or indeed to the wider region of South East Asia. In contemporary Thailand, however, resonances of beliefs concerning the sexualised female form and its supernatural connections to (dark) power(s) continue to fuel constructions of modern femininities. In Siamese folk belief menstrual blood is not merely a pollutant, as it is in so many parts of the world. Rather, its magical properties - ones that traditionally require women's undergarments to be hung out to dry separately and at a lower level than male clothing on the washing-line - relate not only to a narrative of contamination but to the debilitation of male virility and strength. The early fifteenth-century chronicle of the Camadevivimsa, for example, narrates the tale of how the Mon princess Camadevi of Haripunjaya (present-day Lamphun in Northern Thailand) incapacitated her male suitor-cum-opponent by fashioning for him a headdress from a loincloth stained with her own menstrual blood. Once

${ }^{13}$ Although without English subtitles, a clip of the full speech is available at https://www.youtube.com/watch?v=AZZWAac6q6s\&list=PLKMKzrWiWj1Cgw3f AAZGSpFs9jueaE3Eh\&index=1 [last accessed 21 May 2016]

14 See, for example, the response of Dr Pradit Sintavanarong reported on https://www.hfocus.org/content/2014/01/6104 [last accessed 21 May 2016] 
This is the accepted version of a forthcoming article that will be published by Springer in Feminist Review: https://link.springer.com/journal/volumesAndlssues/41305

Accepted version downloaded from SOAS Research Online: http://eprints.soas.ac.uk/24349/

having donned it, the prince was rendered unable to fire his arrows into her kingdom (literally, so the story goes, but one has to assume also metaphorically as well). (See Swearer and Sommai 1997.) Mirroring the hierarchies of Thai washing-line etiquette, the spiritual superiority of the (male) head is polluted by the base inferiority of the (female) genitalia and its ominous web of reproductive passages.

Yet neither of these examples of traditional belief and practice serves to fully explicate Dr Prasert's proposal to personally administer Yingluck's sanitary towel supplies. Rather, his defiance of the polluting and emasculating properties of her menstrual blood, speak of a gendered challenge to her female potency; of an objectifying intervention into her female privacy with the purpose of sanitizing her physical impurities (for which read, also, moral ones); and an infantilization of her body, equating sanitary towels with disposable nappies and menstrual blood with uncontrolled flows of urine and faeces. According to renowned cultural critic and TV-host Lakhana Punwichai (pseud. Kham Phaka), whose feminist interpolations are further discussed below, Dr Prasert's comments can be explained as an oath of self-sacrifice to encourage Yingluck to resign:

The doctor wants to convey the message that Yingluck has people supporting her simply because she is currently the PM (which means she must be really terrible and that no one loves her); Yingluck refuses to step down from her position as PM because she is afraid that when she is no longer in power then she will have no one left around her. Therefore, in 
This is the accepted version of a forthcoming article that will be published by Springer in Feminist Review: https://link.springer.com/journal/volumesAndlssues/41305

Accepted version downloaded from SOAS Research Online: http://eprints.soas.ac.uk/24349/

order to persuade Yingluck to resign, the doctor will be the only person in the world to stay by her side and will even be selfless enough to change her sanitary towels for her (i.e. expose himself to the most polluted scenario imaginable). ${ }^{15}$

Prasert's ultimate aim is to present the sexualised and fertile body of his female opponent as utterly abject - while casting himself in the role of self-sacrificing champion of (political/moral/physical) purification. It is even conceivable that he drew inspiration for this valiant cause by having won an "Exemplary Democratic Family" award (rangwan khrop khrua prachathipatai tua yang) from the National Identity Office in the preceding year.

The thrust of Dr Prasert's proposed intrusion mirrors the suppression of the "monstrous-feminine" in Thai cultural discourses through the (re)establishment of patriarchal power and order. In discussing this response to the premiership of Yingluck, I adopt the term introduced in the discussion of the interrelationship between film, feminism and psychoanalysis by Barbara Creed (1993 and 2004). Writing on the abject character of the "monstrous-feminine" in Western horror film, Creed elects the specific usage of "monstrous-feminine" to distinguish from the "female monster", which she argues simply implies a reversal of "male monster". As she goes on to clarify:

The reasons why the monstrous-feminine horrifies her audience are quite different from the reasons why the male monster horrifies his audience. A

15 Private email correspondence, 2 May 2016, translated from Thai. 
This is the accepted version of a forthcoming article that will be published by Springer in Feminist Review: https://link.springer.com/journal/volumesAndlssues/41305

Accepted version downloaded from SOAS Research Online: http://eprints.soas.ac.uk/24349/

new term is needed to specify these differences. As with all other stereotypes of the feminine, from virgin to whore, she is defined in terms of her sexuality. The phrase 'monstrous-feminine' emphasizes the importance of gender in the construction of her monstrosity. (Creed, 1993: 3)

Creed's approach to the "monstrous-feminine" is based on her conviction that, "[a]ll human societies have a conception of the monstrous-feminine, of what it is about woman that is shocking, terrifying, horrific, abject" (ibid.: 1). While this appears to be broadly the case, the universal nature of Creed's claim derives from a culturally limited set of texts, drawn largely from Hollywood filmmaking (Alien, Carrie, The Brood, Psycho, The Exorcist etc.) and analytically interrogated through the lens of Freudian psychoanalysis via the work of Julia Kristeva. As Creed opines with reference, for example, to Kristeva's Powers of Horror: An Essay in Abjection (1982):

Although this study is concerned with literature, it nevertheless suggests a way of situating the monstrous-feminine in the horror film in relation to the maternal figure and what Kristeva terms 'abjection', that which does not 'respect borders, positions, rules' ... that which 'disturbs identity, system, order' (p.4). In general terms, Kristeva is attempting to explore the different ways in which abjection as a source of horror, works within patriarchal societies, as a means of separating the human from the nonhuman and the fully constituted subject from the partially formed subject. 
This is the accepted version of a forthcoming article that will be published by Springer in Feminist Review: https://link.springer.com/journal/volumesAndlssues/41305

Accepted version downloaded from SOAS Research Online: http://eprints.soas.ac.uk/24349/

Ritual becomes a means by which societies both renew their initial contact with the abject element and then exclude that element. $(2004,68)$

Kristeva's theory of the abject offers a way of understanding how woman is made monstrous in relation to her bodily, sexual and reproductive functions (ibid. 44), much in the same way that former PM Yingluck Shinawatra's body is made monstrous by her political opponents. Nevertheless, while the question of the maternal figure as abject, and hence a threat to the moral, spiritual and social status quo, is highly relevant to Thai cultural studies and to instances of its cinematic horror genre, Kristeva and Creed's Eurocentric focus on the stable "self" as wholly formed may well be less so. Creed's contention that the horror film "puts the viewing subject's sense of a unified self into crisis" (ibid. 53) is far more culturally specific than it acknowledges. Rather, it points to certain limitations in adopting theoretical positions derived from monotheistic cultural traditions and from Judaeo-Christian philosophical thought committed to the notion of a unified self. ${ }^{16}$ Nor too does the notion that, "An encounter with abject things (death, the corpse, cannibalism) effects a renewal of the individual's sense of self and civilisation. Thus the abject is essential to the process of defining and safeguarding what constitutes the self and civilisation." (Creed, 2004: 36) resonate in the Thai religio-psychological context. Creed's allusion, however, to the role of ritual, whether in terms of actual practice or through cinematic representation, applies as much to Thailand as it does to Hollywood. Ritual, or

\footnotetext{
16 My thanks go to Peter A. Jackson, Leon Redler, Atit Pongphanit and Ashley Thompson for sharing their views with me on this subject.
} 
This is the accepted version of a forthcoming article that will be published by Springer in Feminist Review: https://link.springer.com/journal/volumesAndlssues/41305

Accepted version downloaded from SOAS Research Online: http://eprints.soas.ac.uk/24349/

the cinematic performance of such (which, in turn, becomes ritualistic) serves to exclude the threat posed by the monstrous-feminine to "the order" of things.

In Thailand, parallels with Creed's monstrous feminine are to be observed in both popular beliefs in female spirits and ghosts, and in the horror films that draw inspiration from these beliefs. One such example is found in tales of "widow ghosts" (phi mae mai) - the sexually voracious spirits of women who have met an untimely and probably violent death (Mills, 1995: 250). Used in Thai to refer to any woman who has lost a husband, either as a result of his death or through divorce or separation, the defining feature of the term mae mai is that she is a woman who has known sexual experience. Suspicion of her arises, however, from the fear that her unleashed carnal desires now stand unfulfilled. In her ghostly incarnation (as phi), her sexual appetite, as Mary Beth Mills confirms from ethnographic research conducted in North East Thailand (Isan) in 1990, is "both virtually unquenchable and potentially fatal to the living who become its targets" (Ibid. 250). As such, the widow ghost "is thought to come to a man in a dream, often taking the form of a young and beautiful woman; she lies down upon him, draining him of strength and life but leaving no other sign. To the victim's friends and family, the man simply goes to sleep one night and never wakes up." (Ibid., 251) ${ }^{17}$

\footnotetext{
${ }^{17} \mathrm{~A}$ number of B-grade Thai horror films - such as the rather unimaginatively named series Phi Mae Mai, Phi Mae Mai 3, and Phi Mae Mai 5 - depict the antics of their lustful heroines in quasi-comical mode. Another - Trainee Widow Ghosts (Phi mae mai pai daeng) - opens in the underworld with a gaggle of wellendowed and scantily clad Amazon women cackling, preening and canoodling with each other as they plot their desirous offensives on their hapless male victims above ground.
} 
This is the accepted version of a forthcoming article that will be published by Springer in Feminist Review: https://link.springer.com/journal/volumesAndlssues/41305

Accepted version downloaded from SOAS Research Online: http://eprints.soas.ac.uk/24349/

\section{Whose Utopia? Disrupting, Re-establishing and Resisting the "Order of Things"}

As in the case of the "widow ghosts" discussed above, almost the entire pantheon of Thai ghosts and spirits are gendered female, their expressions of abjection frequently centred on their fertility, maternity and sexuality. One of the bestknown myths to exemplify this trope is the story of Nang Nak, a young woman who dies in childbirth while her husband, Mak, has been conscripted into the army. Due to the romantic attachment that persists between them, Nak returns to the marital home as a ghost (complete with ghoulish infant in her arms) and, fending off all rivals for Mak's affection with irascible cruelty, continues to keep house. Although the story of Nang Nak has been told and re-told, orally, in comic books and magazines and in numerous cinematic versions, the first attempt to reinterpret the legend as quasi-historical fact came in 1999 with Nonzee Nimibutr's glossy production Nang Nak. In Nonzee's rendition of the tale, the date is 1868, the final year of the reign of "pro-modernizing", "ultra rational" and science-loving, King Mongkut (the same monarch that is the focus of attention in The King and I and who ascended the Siamese throne in 1851). Mak returns from battle, shell-shocked and disorientated, to find his deceased wife and newborn in convincingly living form. Nak tends to Mak's every need, while keeping the neighbours at bay lest they inform him about the illusion of which he is unwittingly a part. It is only when Mak catches sight of his wife extending her arm to unnatural length to scoop up a lime that she has dropped between the 
This is the accepted version of a forthcoming article that will be published by Springer in Feminist Review: https://link.springer.com/journal/volumesAndlssues/41305

Accepted version downloaded from SOAS Research Online: http://eprints.soas.ac.uk/24349/

floor boards of their house, that Mak realises there is a truth to the rumours of her death. When a Brahmin ghost-buster fails to rein in Nak's malignant spirit, Mak oversees the exorcism of his wife's ghost by the high-ranking Buddhist abbot - the historical figure of High Dignitary Somdet To - whose spiritual powers are sufficiently superior to be able to bring Nak back under (patriarchal) control. In doing so, Somdet To hacks out a section of her forehead to release the evil spirits that lie within, and is able to lay her tormented soul to final rest. Compounding the abbot's Buddhist sense of order, Mak ordains as a monk, cremates Nak's body, and only hopes to remarry her in a future incarnation. In addition to its deeply conservative, royalist and nationalistic overtones, the narrative further celebrates the superior spiritual power of patriarchy in overcoming the monstrous, post-partum female form, as May Adadol Ingawanij (2007:185) confirms in her assessment of the film:

The overall shape of the narrative is in the end revealed to be a Buddhist quest, in which the decent human husband passes into the next stage of manhood; while the love-struck spirit wife learns to suppress her untamed longing and acknowledges her sin in murder, enlightened by a figure whose narrative power comes from his connotative association with the aura of the national past.

The power struggle that ensues between the traditional, male forces of "good" on the one hand, and the obsessively loving yet threatening ghost of Nak, on the other, encapsulates the wider struggle that pertains between two opposing realms: the rational, enlightened, and conservative-nationalist masculine thrust, 
This is the accepted version of a forthcoming article that will be published by Springer in Feminist Review: https://link.springer.com/journal/volumesAndlssues/41305

Accepted version downloaded from SOAS Research Online: http://eprints.soas.ac.uk/24349/

perceived as being "modern", and represented by Siam's political and cultural elite at the centre; and the unrestrained, supernatural expressions of the feminine as sexualised body, aligned with the a supposedly pre-modern "irrationality" of "the natural world" at the periphery. A distinction prevails between "modern" expressions of power - framed as "civilised" and utopian and "pre-modern" forms of potency - perceived as the barbarous forces of a threatening dystopia. Whereas the sexual threat posed by the rampaging "widow ghosts" is brought under control through recourse to the primitive metaphor of the giant phallus, in Nonzee's Nang Nak, the marauding female spirit is incapacitated through the intervention of a high-ranking Buddhist abbot associated with a modernising monarch renowned for having purified the "national" religion. The relationship between Mak and his overly attached spiritwife is hence rendered morally healthy in spiritually civilised and "properly gendered" terms. We are reminded here of Alderman's apposite comments, in relation to feminist dystopian dreams, quoted at the opening of this paper:

Utopias and dystopias can exist side by side, even in the same moment. Which one you're in depends entirely on your point of view. [...] the relationship between our world and utopias or dystopias of all stripes is a complicated one. [...]Every utopia contains a dystopia. Every dystopia contains a utopia. (Alderman, 2017)

A contrasting, and innovatively dystopian, alternative to the orthodox conclusion of the horror film genre, whereby the monstrous-feminine is restrained and the patriarchal status quo restored, is, however, provided by Thai male director 
This is the accepted version of a forthcoming article that will be published by Springer in Feminist Review: https://link.springer.com/journal/volumesAndlssues/41305

Accepted version downloaded from SOAS Research Online: http://eprints.soas.ac.uk/24349/

Yuthlert Sippapak's 2003 blockbuster Buppha Ratree, Flower of the Night.

Buppha Ratree is from a lower middle class, rural and sexually abusive background, all of which contributes to her introverted isolation when she becomes a student at a Bangkok university. There she is romantically pursued by cosmopolitan posh-boy Ake, unaware that when she finally agrees to sleep with him she is merely the stake in a wager between him and his wealthy male friends. Ake wins a bottle of scotch for bedding Buppha, who is shown to have silently sobbed her way through the sexual encounter as a result, we later discover, of having been abused by her stepfather. Buppha falls pregnant. Ake expresses some remorse for treating her as a pawn in a bigger game and promises to marry her; but instead he follows his mother's instructions to take her for a back-street abortion, deserting her once he has dropped her back home and immediately leaving, unbeknown to Buppha, to study abroad. Alone in her dreary apartment Buppha bleeds to death, only to return as a vengeful ghost to haunt her neighbours. A string of male ghost busters are sent in to relieve the terrified residents of Oscar Apartments, the apartment block where much of the film is set. As the cover image of the DVD release of the movie indicates, various forms of exorcism are attempted to purify flat 609 where Buppha lives: firstly a sham Chinese shaman; then a jumpy Brahmin priest; then a Thai Catholic Father and his Western sidekick, Brother (nod-to-The Exorcist) Damian; and finally a Khmer spiritual healer of superior magical powers. Each and every one of their interventions proves futile, however, and, unlike in Nonzee's Nang Nak, Yuthlert does not introduce the viewer to the final resolution of a superior Buddhist monk. Hence the ghost of Buppha cannot be put to rest. The closing scene depicts Buppha in full control of the deserted terrain of Oscar Apartments, watching 
This is the accepted version of a forthcoming article that will be published by Springer in Feminist Review: https://link.springer.com/journal/volumesAndlssues/41305

Accepted version downloaded from SOAS Research Online: http://eprints.soas.ac.uk/24349/

over her mutilated ghost-partner Ake, who rejoined her following his death from a drug overdose in London. He lies crippled on the floor, having had his genitals scolded with hot rice soup and his legs hacked off by Buppha to punish his philandering. Ake pleads for forgiveness as Buppha "lives" on, having achieved a kind of pyrrhic victory, reigning dejectedly over a dystopian urban landscape.

Given the significance of Nang Nak as Thailand's ghost story par excellence (see, for example, McDaniel, 2007; and Furhmann, 2016), it is unsurprising that the tale of Buppha Ratree: Flower of the Night bears similarities to Nang Nak in terms of narrative structure. Like Nak, Buppha's pregnancy results in her death and her reappearance in ghostly form to find her lost lover, to settle old scores and to take revenge upon the surrounding community. Like Nonzee's film version of Nang Nak, Yuthlert's Buppha Ratree suggests an interplay between the rural and the urban, the periphery and the centre. As May Adadol (2007) posits, the resolution of Nang Nak represents an establishment of control over the countryside by the superior spiritual forces of a Buddhist monk from the city/palace; and in Buppha Ratree a ghost from the periphery, in both class and geographical terms, traumatises a low-brow urban community as a result of wrongdoings against her by the collusions of a metropolitan elite. Mirroring the tensions symbolised by the appearance of "widow ghosts" in Isan, both Nang Nak and Buppha Ratree similarly reflect the pervasive Thai cultural dichotomies of the rational and the supernatural; the civilised and the primitive; the morally and spiritually superior masculine order versus the chaos of the "monstrousfeminine". Nevertheless, they each do so from rather different perspectives: while Nang Nak, as discussed above, proclaims a sympathetic, yet nevertheless 
This is the accepted version of a forthcoming article that will be published by Springer in Feminist Review: https://link.springer.com/journal/volumesAndlssues/41305

Accepted version downloaded from SOAS Research Online: http://eprints.soas.ac.uk/24349/

effective resolution to the disorder wrought upon the village community by Nang Nak, Buppha Ratree, by contrast, registers a failure in patriarchal, spiritual control, allowing the "monstrous feminine" to persist. Yuthlert's Buppha transforms from a disempowered and abused young student to the emboldened and vengeful regulator of a dystopian urban space.

It would be imprecise, however, to read this portrayal of Buppha as a genuinely feminist representation. Created by a successful, Bangkok-based filmmaker of originally rural, Isan origins, Buppha's purpose is to serve as an admonition, in Yuthlert's own view, to Thai men who fail to treat women fairly. ${ }^{18}$ For Yuthlert, Buppha is therefore less a feminist heroine in her own right than she is an educational tool for male sexual etiquette, one through whom men learn how to respect female purity and not besmirch women's "honour" with the threat of sex. Nevertheless, she is open to reinterpretation, when refocused through the lens of self-avowedly feminist Thai thinkers such as Kham Phaka.

\section{Feminist Strategies of Empowerment: Speaking as a Slut}

I never understand why it is that Thais believe that being a Thai woman means having to be more composed, well-mannered and reserved than the women of any other nation in the world, especially those of the West. Whenever people encounter phrases like "the honour of Thai women" or "the qualities of the Thai gentlewoman" it gets their nationalist blood up

\footnotetext{
18 Personal interview with Yuthlert Sippapak, Bangkok, 2009.
} 
This is the accepted version of a forthcoming article that will be published by Springer in Feminist Review: https://link.springer.com/journal/volumesAndlssues/41305

Accepted version downloaded from SOAS Research Online: http://eprints.soas.ac.uk/24349/

and leads them to the misunderstanding that our own nation's female "private parts" (jim) are cleaner than anyone else's. (Kham Phaka 2003, 254-255)

Such is the opinion of the Thaksin-sponsored Voice TV channel presenter Lakhana Punwichai, taken from her earliest collection of articles Krathu dok thong. The book was first published in 2003, and is roughly translatable as Queries from a Common Slut the tenor of which mirrors the underlying meaning of her pseudonym, Kham Phaka, literally "golden flower". While the association with a flower is a common one in elegant Thai female names, the attribute of "golden" alters the tone, shifting to a customary allusion to female sexual promiscuity. Roundly condemned as "a tainted woman who violates Thai morals, cultural beliefs and traditions" (Anon. 2004) and the target of widespread negative opinion from her "enemies" (Viengrat 2013, 8), Kham Phaka's strategy has always been one of deliberate provocation, controversy and scandal. In April 2012, for example, she went off air for one month due to harsh criticism from the conservative Buddhist clergy, to whom she had caused offence. ${ }^{19}$ And since her earliest appearance on the Thai academic and media scene at the beginning of the millennium, Kham Phaka has made a reputation for herself as an outspoken freelance columnist and social critic, writing for numerous weekly news magazines such as the well established Matichon Sutsapada. Her collected articles have often been subsequently republished in

${ }^{19}$ See https://www.prachatai.com/english/node/3159 [last accessed March 2017] 
This is the accepted version of a forthcoming article that will be published by Springer in Feminist Review: https://link.springer.com/journal/volumesAndlssues/41305

Accepted version downloaded from SOAS Research Online: http://eprints.soas.ac.uk/24349/

book form, as exemplified by Queries from a Common Slut (part of which is also available in annotated English translation in Harrison 2014).

With reference to the tenor and content of Kham Phaka's extensive commentary on both contemporary and historical Thailand, I now wish to explore the embrace of the Thai primitive, the abject and the supernatural not as dystopian and monstrous, as it is in the Thai horror genre, but rather as a knowingly reinvented utopian space of freedom of expression and dissent from the "norm"; one that answers back to social, cultural, emotional, sexual and political repression in contemporary Thailand. ${ }^{20}$ The contribution of Thai feminists such as Kham Phaka exemplifies ways in which archaic and mythical forms of female power can be appropriated and recast via the assumption of a dystopian or counter-cultural vision. In this sense, I argue, Kham Phaka goes against the grain of being a good, virtuous, demure and sexually moral woman of the sort ideally imagined by the film director of Buppha Ratree for his heroine. And this Kham Phaka attempts by reclaiming female sexuality not as threat but as rightful pleasure and desire.

Kham Phaka's penetrating analyses of Thai literary classics in Queries from a Common Slut provides one example of how she initiated this cultural project, one in which she confirms her focus on women who inspire her conclusions:

\footnotetext{
${ }^{20}$ See also Chanokporn Chutikamoltham (2016) on the monstrous-feminine and the return of the repressed in Thai popular culture.
} 
This is the accepted version of a forthcoming article that will be published by Springer in Feminist Review: https://link.springer.com/journal/volumesAndlssues/41305

Accepted version downloaded from SOAS Research Online: http://eprints.soas.ac.uk/24349/

What I propose in my columns is no more than a demonstration, my own liberation from the powers of the authors of popular fiction. Most significantly I determine to deconstruct the binary opposition of the heroine/"perfect lady" and the antagonist/whore. (Kham Phaka 2003, 292-293)

Among the best illustrations of Kham Phaka's deliberately dystopian readings of modern Thai literary classics is her reinterpretation of the demure and decorous heroine of Siburapha's 1937 novel Behind the Painting (Khang lang phap). In Kham Phaka's reassessment of this text, the newly wed Khunying (Madame) Kirati is a self-proclaimed virgin, fast approaching middle age and "gagging for" a sexual encounter with her much younger friend Nopphorn:

So many women who have read this novel or watched the film versions of Behind the Painting cannot hold back their tears of pride in the great honour displayed by the beautiful Kirati, who stays true to the undying love she has for Nopphorn. Were I to shed a tear for Kirati, however, it would not be because she dies without having anyone to love her, but because she goes and dies without anyone understanding that she is a woman with physical needs and desires, with a need for sexual pleasure, just like any other human being. Without this understanding, we all make the same mistake as Nopphorn: we make the error of putting Kirati on a pedestal and never wanting to see her experiencing the sexual pleasure for which she actually longs. We leave her to build her dreams all alone; it 
This is the accepted version of a forthcoming article that will be published by Springer in Feminist Review: https://link.springer.com/journal/volumesAndlssues/41305

Accepted version downloaded from SOAS Research Online: http://eprints.soas.ac.uk/24349/

is therefore hardly surprising that she simply gives up the ghost and dies!"

In placing the taboo topics of female sexual desire, pleasure and fulfilment centre stage in her re-reading of this text, Kham Phaka's overriding aim is not purely a cultural one but also broadly political. Her emphasis is not simply on constructions of Thai femininity, their effect in popular fiction and the consequent need to redefine them, but also on how these creations serve a conservative national agenda-one that, in Kham Phaka's view, is deeply exploitative of women. As a result of this, her work goes beyond that of sexual equality to imply a much wider-ranging, radical political endeavour, serving to disrupt the workings not only of patriarchy but also of the Thai nation-state itself. This radical stand is arguably derived, at least in part, from Kham Phaka's own particular background (Viengrat, 2013) not only as female but also as provincial, both in cultural and in educational terms. Born and educated in the Northern Thai province of Chiangmai, she occupies a rare position among the largely Bangkok-based Thai intellectuals that enables her to look at Thai culture from a "subaltern" perspective. The result is an ability to connect more positively with pre-modern, pre-urban forms of expression, to challenge the visions of utopia constructed by the Bangkok elite, and to counter them with deliberate displays of the "monstrous-feminine" as a potent female force.

Kham Phaka's three-volume series of books entitled Ko phrai ni kha (I Am a Commoner. So What?) provides one of several instances of this approach, adopting the archaic term of phrai, or serf that was revivified by the Red-Shirt 
This is the accepted version of a forthcoming article that will be published by Springer in Feminist Review: https://link.springer.com/journal/volumesAndlssues/41305

Accepted version downloaded from SOAS Research Online: http://eprints.soas.ac.uk/24349/

movement in their acknowledgement of Thailand's trenchantly feudalistic interpersonal relationships and hierarchies. And, in 2011, she introduced postfeminist tactics in the campaign against Thailand's notorious lèse-majesté law, Article 112, posing naked from the neck down to the waist, the words "No Hatre[d] for Naked Heart" scrawled in dripping black ink across her breasts. ${ }^{21}$ The opposing, ultra-royalist Yellow-Shirt news journal ASTV-Manager Weekly quipped back with criticism predictably "dismissive" in flavour, under the headline "Kham Phaka flaunts her breasts to topple the Monarchy" (Anon 2011, 1). Seemingly humorous and light-hearted, the accusation against her is a serious one, given that the dramatic rise in the number of successful prosecutions for the slightest hint of anti-monarchist sentiment in Thailand has resulted in lengthy prison sentences for many. What Kham Phaka's stance exemplifies is the way in which Thai discourses of the body and of female sexuality might be deployed as part of a strategy of symbols to disturb the status quo and to ripple the surface of certain forms of political, cultural and sexual silencing. It is not by coincidence that one of the first ways in which Kham Phaka grabbed the public's attention was by flaunting all norms of Thai female propriety in choosing to pose naked for a leading Thai men's magazine, GM Plus. The feature also included a candid interview, providing details of her own sex life. Explaining this choice as a statement in support of her writing about the female body and her denial of standards constructed by social values, Kham Phakaa further aimed to show that, "when a woman is naked, it does not mean that she is a victim [...] My question is this: Is a woman degraded when she

${ }^{21}$ Kham Phaka's adoption of the term post-feminist is deployed in the deliberate flaunting of her naked body, which she sees an antithetical to the strategies of earlier Thai feminist practice. 
This is the accepted version of a forthcoming article that will be published by Springer in Feminist Review: https://link.springer.com/journal/volumesAndlssues/41305

Accepted version downloaded from SOAS Research Online: http://eprints.soas.ac.uk/24349/

willingly undresses herself before the public? Will people lose faith in her other work? Is this worse when compared with other big crimes like corruption?"22

Kham Phaka calls attention here to the contrasts between the demure Thai female body - unexposed and hence "morally upright" - and the social and cultural disgrace of nakedness. These codes of aesthetics and morality have been inscribed in Thai femininity since at least the mid nineteenth century and are tightly intertwined with the "utopian" vision of the "good" Thai woman as metaphor for the "good" Thai nation-state. Looking good means being good in a culture where close attention to appearances and surfaces relate, in turn, to (appearance of) moral virtue. ${ }^{23}$ It is arguably for these cultural reasons that the military government that took power in Thailand in May 2014 has paid such close attention to the policing of the female body. Hence, under Thai military rule, women have been warned not to appear topless in ribald Songkran (Thai New Year) festivities; ${ }^{24}$ and the circulation of "underboob" selfies on social media has been made not only illegal but punishable by up to five years in prison since March 2015. Invoking the 2007 Computer Crimes Act, this prohibition related to government concerns that the underboob might "cause damage to the country's security or cause public panic". Indeed, Prime Minister Prayut's own concerns for the decorous nature of the female body were inadvertently revealed

${ }^{22}$ Kham Phaka quoted in 'Sunday style' in The Nation on Sunday, 24 October 2004.

${ }^{23}$ See in particular the work of Jackson, 2004; and Morris, 2000, both of whom develop this important argument in relation to Thai cultural practice. ${ }^{24}$ See 'Thai PM warns drunk drivers, topless dancers ahead of Songkran festival' in Asian Correspondent, 6 April 2016. Available at: https://asiancorrespondent.com/2016/04/thai-pm-warns-drunk-driverstopless-dancers-ahead-of-songkran-festival [last accessed 2 February 2017]. 
This is the accepted version of a forthcoming article that will be published by Springer in Feminist Review: https://link.springer.com/journal/volumesAndlssues/41305

Accepted version downloaded from SOAS Research Online: http://eprints.soas.ac.uk/24349/

in unfortunate remarks to the press made in the aftermath of the rape and murder of British tourists Hannah Witheridge and David Miller on the island of Koh Tao in September 2014: "Tourists think that Thailand is beautiful, safe and that they can do anything they want here. That they can put on their bikinis and go anywhere they want. I ask, can you get away with wearing bikinis in Thailand? Unless you are not beautiful?"

Beauty and the Beast: Some Conclusions

The concerns of the Thai state as to what is morally appropriate and aesthetically desirable on the one hand, or dangerously alluring and sexually threatening on the other, is currently under rigorous enforcement by military rule, at least in relation to what appears in the public, if not the private, domain (see, also, Jackson 2004). The seizure of power by the Thai military has produced an apparently "joyous" construction of a version of utopia that garners considerable popular support among ultra-royalist and conservative Thais, largely, though not entirely, confined to Bangkok, its environs and the southern region of the country. The price to be paid for this post-Yingluck sense of "moral order" and political propriety, however, is that of the democratic voice. Large swathes of the country's north, and northeastern (Isan) regions, known as Thailand's Red-Shirt heartlands, no longer have the opportunity to exercise their own choice of government. Hence they remain politically silenced and, in their (inexpressible) view, unrepresented. Their plight is paralleled in cultural terms by Thailand's perception of the monstrous-feminine, the repressed figure of 
This is the accepted version of a forthcoming article that will be published by Springer in Feminist Review: https://link.springer.com/journal/volumesAndlssues/41305

Accepted version downloaded from SOAS Research Online: http://eprints.soas.ac.uk/24349/

rampaging and sexually voracious female power. And it is for this reason that Yingluck Shinwatra's opponents so frequently alluded to her sexuality and her maternity to undermine her. In this they followed the tropes of deeply embedded beliefs in horror and abjection, all that should be expelled in the process of restoring a male-dominated moral symbolic and political power.

Given this patriarchal vision of what constitutes the utopian Thai state, the voices and images that the vision excludes are faced with making their presence felt from the cultural, geographical and political periphery. In labelling her the product of a dystopia, anti-Yingluck forces continue to restrict her role in mainstream politics. ${ }^{25}$ While Yingluck's response to criticism throughout and following her period in office was to remain polite, demure, diplomatic and composed, this article explores alternative approaches which women - in Thailand and beyond - may adopt in relation to the enforcement of militarised and patriarchal constructions of hyper-masculinised utopias. In Thailand, postfeminist strategies of liberation, such as those embodied by the cultural commentator Kham Phaka, present calculatingly "dystopian" counter discourses in protest. The means by which they achieve this is through a conscious inversion of the deeply embedded cultural and aesthetic norms of the "centre" that connect so closely to the power of the Thai state. The very meaning of Kham Phaka's pen name, together with the views that she proffers on the acceptability of female sexual desire, draw provocative potency from the age-old taboos that she thrusts into the public domain. She and her work become a haunting spectre

${ }^{25}$ After her overthrow Yingluck was charged with criminal negligence over her failed flagship rice subsidy scheme. 
This is the accepted version of a forthcoming article that will be published by Springer in Feminist Review: https://link.springer.com/journal/volumesAndlssues/41305

Accepted version downloaded from SOAS Research Online: http://eprints.soas.ac.uk/24349/

- a deliberate display of the monstrous-feminine that threatens to ruffle the "utopian" surfaces of power. Not only is this a feminist response to male power, but also a peripheral response to the centre, a challenge from the rural and the low brow the imagined "sophistication" of the metropole.

\section{$\underline{\text { References }}$}

Alderman, Naomi. 2017. "Dystopian dreams: how feminist science fiction predicted the future". The Guardian, 25 March.

https://www.theguardian.com/books/2017/mar/25/dystopian-dreams-howfeminist-science-fiction-predicted-the-future [last accessed 23 April, 2017]

Anon. 2004. "The nude scholar". The Nation "Sunday Style”, October 24, 2004.

Anon. 2011. "Kham Phaka" pleuay nom "lom jao"!? kap withi haeng dok thong. [Kham Phaka Shows Her Breasts to Topple the Monarchy!? And the Methods of the Slut.] ASTV-Phujatkan Sut-sapada [Manager Weekly]. December 10. http://www.manager.co.th/AstvWeekend/ViewNews.aspx?NewsID=954000015 $\underline{7179}$ [last accessed 23 April, 2017].

Berry, Chris, Annette Hamilton and Laleen Jayamanne [eds.], 1997. The Filmmaker and the Prostitute. Dennis O' Rourke's The Good Woman of Bangkok. Sydney: Power Publications. 
This is the accepted version of a forthcoming article that will be published by Springer in Feminist Review:

https://link.springer.com/journal/volumesAndlssues/41305

Accepted version downloaded from SOAS Research Online: http://eprints.soas.ac.uk/24349/

Chanokporn Chutikamoltham, 2016. Destabilizing Thainess. The Construction of

National Culture in State Ideologies and the Return of the Repressed. PhD Thesis, SOAS, University of London.

Creed, Barbara, 1993. The Monstrous-Feminine: Film, Feminism and Psychoanalysis. London and New York: Routledge.

---- . 2004. Pandora's Box. Essays on Film Theory. Flinders Lane, VIC, Australia: Australian Centre for the Moving Image.

Furhmann, Arnika, 2016. Ghostly Desires. Queer Sexuality and Vernacular Buddhism in Contemporary Thai Cinema. Durham and London: Duke University Press.

Harrison, Rachel, 2012. 'Disturbing Conventions'. The Newsletter, IIAS, No. 59, Spring 2012. http://www.iias.asia/sites/default/files/IIAS_NL59_2627.pdf

Harrison, Rachel (ed.), 2014. Disturbing Conventions: Decentering Thai Literary Traditions. London: Rowman and Littlefield International.

Jackson, Peter A., 2004. “The Thai Regime of Images”. In Sojourn Vol. 19, No. 2 (October 2004), pp. 181-218

Johnson, Andrew Alan, 2014. Ghosts of the New City: Spirits, Urbanity, and the Ruins of Progress in Chiang Mai. Honolulu: Hawaii University Press. 
This is the accepted version of a forthcoming article that will be published by Springer in Feminist Review: https://link.springer.com/journal/volumesAndlssues/41305

Accepted version downloaded from SOAS Research Online: http://eprints.soas.ac.uk/24349/

Kham Phaka, 2003. Krathu dok thong (Queries of a Common Slut). Bangkok: Phraew Samnakphim.

Kham Phaka, 2013. Ko phrai ni kha. (I am a Commoner. So What?). Vol. 3.

Bangkok: Samnakphim An.

Kong Rithdee. 2017. "When history becomes just a hazy dream”. In Bangkok Post, 22 April 2017. http://www.bangkokpost.com/opinion/opinion/1236326/when-historybecomes-just-a-hazy-dream [last accessed 23 April 2017].

Kristeva, Julia, 1982. Powers of Horror: An Essay in Abjection. New York: Columbia University Press.

Latour, Bruno, 1993. We Have Never Been Modern. [transl. by Catherine Porter.] Cambridge, Massachusetts: Harvard University Press.

May Adadol Ingawanij, 2007. 'Nang Nak: Thai Bourgeois Heritage Cinema'. In Inter-Asia Cultural Studies, Volume 8, Issue 2, pp. 180-193.

McCargo, Duncan and Ukrist Pathmanand. 2004. The Thaksinization of Thailand. Copenhagen: NIAS.

McDaniel, Justin, 2011. The Lovelorn Ghost and the Magic Monk: Practicing Buddhism in Modern Thailand. New York: Columbia University Press. 
This is the accepted version of a forthcoming article that will be published by Springer in Feminist Review:

https://link.springer.com/journal/volumesAndlssues/41305

Accepted version downloaded from SOAS Research Online: http://eprints.soas.ac.uk/24349/

Mills, Mary Beth, 1995. "Attack of the Widow Ghosts: Gender, Death, and

Modernity in Northeast Thailand". In Aihwa Ong and Michael G. Peletz (eds.),

Bewitching Women, Pious Men: Gender and Body Politics in Southeast Asia.

Berkeley: University of California Press.

Montesano, Michael J., Pavin Chachavalpongpun., \& Aekapol Chongvilaivan. 2012. Bangkok May 2010: Perspectives on a divided Thailand. Singapore: Institute of Southeast Asian Studies (ISEAS).

Morris, Rosalind C., 2000. In the Place of Origins: Modernity and Its Mediums in Northern Thailand. Durham and London: Duke University Press.

Pasuk Phongpaichit and Baker, Chris, 1998. Thailand's Boom and Bust. Chiangmai: Silkworm Books.

Pasuk Phongpaichit and Baker, Chris, 2000. Thailand's Crisis. Chiangmai: Silkworm Books.

Pasuk Phongpaichit and Baker, Chris. 2002. Thailand, economy and politics (2nd ed.). Oxford: Oxford Univ. Press.

Pasuk Phongpaichit and Baker, Chris. 2004. Thaksin: The business of politics in Thailand. Copenhagen: NIAS. 
This is the accepted version of a forthcoming article that will be published by Springer in Feminist Review: https://link.springer.com/journal/volumesAndlssues/41305

Accepted version downloaded from SOAS Research Online: http://eprints.soas.ac.uk/24349/

Pasuk Phongpaichit and Baker, Chris. (eds.) 2008. Thai capital: After the 1997 crisis. Singapore: ISEAS.

Swearer, Donald and Sommai Premchit, 1997. The Legend of Queen Cama: Bodhiramsi's Camadevivamsa, a Translation and Commentary. New York: SUNY Press. 